Abstracta Iranica

Revue bibliographique pour le domaine irano-aryen

Volume 32-33 | 2013

Comptes rendus des publications de 2009-2010

\title{
Enrico G. Raffaelli. The Astrological Chapter of the Škand Gumānig Wizā
}

Samra Azarnouche

\section{(2) OpenEdition}

1 Journals

Édition électronique

URL : http://journals.openedition.org/abstractairanica/40121

DOI : 10.4000/abstractairanica.40121

ISSN : 1961-960X

\section{Éditeur :}

CNRS (UMR 7528 Mondes iraniens et indiens), Éditions de l'IFRI

\section{Édition imprimée}

Date de publication : 1 décembre 2013

ISSN : 0240-8910

\section{Référence électronique}

Samra Azarnouche, «Enrico G. Raffaelli. The Astrological Chapter of the Škand Gumānīg Wizā », Abstracta Iranica [En ligne], Volume 32-33 | 2013, document 15, mis en ligne le 01 juillet 2016, consulté le 26 septembre 2020. URL : http://journals.openedition.org/abstractairanica/40121 ; DOI : https:// doi.org/10.4000/abstractairanica.40121

Ce document a été généré automatiquement le 26 septembre 2020.

Tous droits réservés 


\title{
Enrico G. Raffaelli. The Astrological Chapter of the Škand Gumānīg Wizā
}

\author{
Samra Azarnouche
}

\section{RÉFÉRENCE}

« The Astrological Chapter of the Škand Gumānīg Wizār », in : Gherardo Gnoli, Antonio Panaino, eds., Kayd. Studies in History of Mathematics, Astronomy and Astrology in Memory of David Pingree. Roma, IsIAO, 2009, p. 105-27 (Serie Orientale Roma 102).

1 Avec cet article, l'A. marque une nouvelle avancée dans son projet de mettre en lumière la doctrine astrologique de l'Iran sassanide. Dans la littérature pehlevie, elle se trouve solidement et volontairement imbriquée dans la pensée dualiste mazdéenne. Un motif récurant est celui du combat entre les étoiles (considérées comme bénéfiques) et les astres mobiles (planètes et comètes, considérées comme malfaisantes). Dans le 4ème chapitre du Škand Gumānīg Wizār, ce motif est employé pour justifier les rôles déterminants (positifs comme négatifs) des corps célestes sur le monde terrestre. En se basant sur des parallèles textuels, notamment celui du Bundahišn, l'A. élucide définitivement ce passage difficile et corrige les leçons de certaines termes par rapport à l'édition de référence (de Menasce, 1945), tels que Məx ī bālistī « haut pivot », pour désigner l'étoile Polaire. 


\section{AUTEURS}

SAMRA AZARNOUCHE

Paris 